\title{
Anatomical Properties of Three Lesser Utilised Ghanaian Hardwood Species
}

\author{
Gladys A. Quartey \\ Department of Interior Design Engineering, Takoradi Polytechnic, Takoradi, Ghana \\ Email: gladnyarko@yahoo.com
}

Received 22 October 2015; accepted 18 December 2015; published 21 December 2015

Copyright (C) 2015 by author and Scientific Research Publishing Inc.

This work is licensed under the Creative Commons Attribution International License (CC BY). http://creativecommons.org/licenses/by/4.0/

(c) (i) Open Access

\begin{abstract}
Wood is composed of mostly hollow, elongated, spindle-shaped cells that are arranged parallel to each other along the trunk of a tree. The characteristics of these fibrous cells and their arrangement affect strength properties, appearance, resistance to penetration by water and chemical solutions, resistance to decay and many other properties. The characterisation of wood helps in identifying them. In this work, we studied the anatomical properties of three lesser utilised Ghanaian hardwood species namely Albizia ferruginea (Guill. \& Perr.) Benth, Blighia sapida K. D. Koenig and Sterculia rhinopetala K. Schum using the light microscope and scanning electron microscope (SEM). Anatomical features studied were fiber length, double fiber wall thickness, fiber proportion, vessel diameter and proportion, rays and axial parenchyma proportions. We observed that the use of SEM in studying the anatomical or ultra-structural aspects of wood gave a clearer understanding of the features and structures found in wood. Anatomical features such as presence of crystals and absence of axial parenchyma in Blighia sapida and the thick wall fibers of Sterculia rhinopetala were better understood.
\end{abstract}

\section{Keywords}

Anatomical Features, Ghanaian Hardwoods, Lesser Utilised, Scanning Electron Microscopy

\section{Introduction}

The utilisation of lesser utilised timber species as replacement for the primary commercial wood species has been a matter of discussion for some time now. This is in the light of many efforts by research institutions such as the Forestry Research Institute of Ghana and Building and Road Research Institute of Ghana, in a bid to stop or minimise the extinction of some of the durable timber species due to overexploitation. The efficient utilisation of these lesser utilised species (LUS) depends on the knowledge of their anatomical properties among others [1]. 
The natural forest resources in several tropical timber producing countries including Ghana are getting exhausted, resulting in reduced availability and quality of the preferred traditional timber species. The author states that although about 70 species are harvested and used commercially out of about 420 which grow to timber size in Ghana's forests, the trade is dominated by about only eight species [2]. According to another author, of the 60 - 64 Ghanaian timber species, it is noted that Afzelia spp., Aningeria spp., Ceiba pentandra, Terminalia ivorensis, Pterygota macrocarpa, Khaya grandifoliola, Tarrietia utilis, Milicia excelsa, Terminalia superba, and Triplochiton scleroxylon are dominated in terms of volume exported [3]. About 160,594 $\mathrm{m}^{3}$ of these species were exported in 2004 [4]. By 2007, the total volume of these species exported had decreased to $97657.6 \mathrm{~m}^{3}$ [5]. Ghana forestry reports in recent years indicate that the species for which Ghana is known in international markets is becoming very scarce. Current thinking is that to reduce the pressures on the popular species, industry must take a close look at the lesser-species (LUS).

The utilisation of lesser utilised timber for bridges has been adopted in other African countries like Cameroon with considerable gain to the economy [6]. Zziwa et al. [7] studied non-traditional timber species used for furniture by Ugandan carpenters. Based on his findings, he urged that fast growing species such Pinus caribea should be planted to cater for the increasing demand for furniture products. In the work of another author, he discussed the possibility of using less known tropical hardwood species to meet the increasing demand on timber [8]. The use of Piptadeniastrum africanum as a promising alternative to Milicia excelsa was also suggested [9]. Furthermore, an author also suggested that the use of lesser utilised wood species would reduce negative ecological imparts such as reduction in biodiversity and desertification [10].

There are several methods of studying the anatomy of wood. These include the use of hand lens, light microscope, and scanning electron microscope. More common techniques employ the use of the light microscope. With the light microscope, one can survey enormous quantities of material in a short time, exploring variability and distribution of features within the wood [11].

In this work, we studied the anatomical properties of three lesser utilised wood species namely Albizia ferruginea (Guill. \& Perr.) Benth, Blighia sapida K. D. Koenig, and Sterculia rhinopetala K. Schum. Some of the findings were that Albizia ferruginea had 63.3\% fibers second to Blighia sapida with 64.3\% of fibers. Sterculia rhinopetala had the lowest percentage of fibers with 43\%. In vessel proportion, Blighia sapida had the proportion of $11.5 \%$ and a vessel density of 12 vessel $/ \mathrm{mm}^{2}$, followed by Sterculia rhinopetala with $7.3 \%$ and vessel density of 7 vessels $/ \mathrm{mm}^{2}$ and Albizia ferruginea with lowest proportion of vessels at $5.8 \%$ and vessel density of 6 vessels $/ \mathrm{mm}^{2}$.

This work will be organised as follows: Section, one introduction; section two, methodology; section three, results and discussion, and finally section four, conclusions and acknowledgements.

\section{Methodology}

Three lesser utilised species Albizia ferruginea (Guill. \& Perr.) Benth, Blighia sapida K. D. Koenig and Sterculia rhinopetala K. Schum were selected for anatomical study. The anatomical study was carried out in the wood anatomy laboratory of the University of Applied Science in Biel, Switzerland. Discs $10 \mathrm{~cm}$ thick were cut from a height of $1.30 \mathrm{~m}$ from the butt of the tree (Figure 1 ).

From each disc samples of $1 \mathrm{~cm} \times 3 \mathrm{~cm}$ were taken from the heartwood portion. They were weighed and their densities determined by the oven dry method. The samples were then softened by first saturating with water and later soaking them in ethanol and glycerol (1:1) in labelled containers for an average period of about 20 - 30 days. Thin sections, 20 - $30 \mu \mathrm{m}$ thick produced on a Leica sliding microtome were first washed in water and then in 1\% safranin in 50\% ethanol solution for about 10 - 20 minutes. After staining they were washed in water and dehydrated in increasing concentrations of ethanol: 30\%, 50\%, 70\%, 85\%, 90\% and 100\%.

After dehydration, they were permanently mounted in Canada balsam. Slides were examined using a Leica DMLM light microscope, and photographs taken using a Leica DFC 320 digital camera. Photomicrographs were then analysed with software Leica 1M 1000 Version 4.0 Release 132. For the Scanning electron microscope (SEM), small wood samples were thoroughly impregnated with an alkyd or acrylic resin and then allowed to cure [12] [13]. The resin was known to be resistant to acids such as $72 \%$ sulphuric acid which was used to remove the cellulose and hemicelluloses from the sample, and to a 50:50 mixture of 10\% chromic and $10 \%$ nitric acids which dissolve the lignin. After careful washing with distilled water, the residue was a negative or cast of the openings in the wood which has been penetrated by the resin. After careful separation of the very small casts, they were dehydrated, mounted on a specimen stub, with a fixative solution of formalin. It was then coated with 


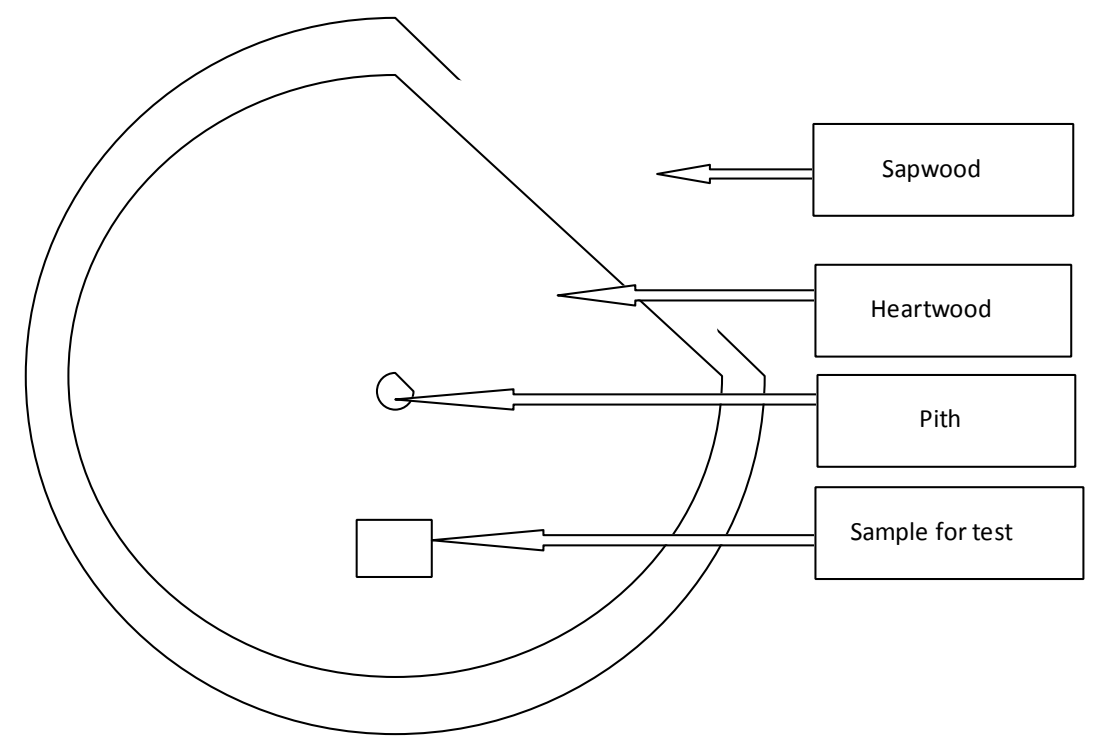

Figure 1. Schematic illustration showing the location of heartwood samples in the disc.

a thin layer of gold in a sputter coater. The prepared sample was then placed in the sample chamber of a scanning electron microscope with a spatial resolution of $8.0 \mathrm{~nm}$ at $5 \mathrm{kV}$. SEM photomicrographs were produced and analysed. Vessel diameter was obtained by measuring 30 randomly selected pore, then taking the average. The frequency of vessels per $\mathrm{mm}^{2}$ was calculated by counting the number of vessels in thirty $1-\mathrm{mm}^{2}$ fields, then taking an average. The micrographs were analysed using the stereological technique (Figure 2) for the proportion of the tissues [14] [15]. Thirty randomly selected micrographs for each tissue studied were used for study and then the averages taken. Dots grid were used to determine area fractions $\left(\mathrm{P}_{\mathrm{p}}\right)$ of anatomical elements and oriented segments of predetermined length were used to determine the number of elements per unit length of the test line in the radial and tangential directions $\left(\mathrm{NL}_{\mathrm{R}} \cdot \mathrm{NL}_{\mathrm{T}}\right.$ ) (Figure 2). Standard areas were used to determine the number of elements per unit area $\left(\mathrm{N}_{\mathrm{A}}\right)$. These basic counts were then used to derive other parameters such as proportion of elements in percentages. Splinters were also taken from the discs and macerated in a solution of equal parts of Acetic acid and hydrogen peroxide and heated in an oven at about $65^{\circ} \mathrm{C}$ for 72 hours.

\section{Results and Discussion}

We performed stereo analysis of the microtome sections. The quantitative anatomical measurements are presented in Table 1. Albizia ferruginea had $63.3 \%$ fibers second to Blighia sapida with $64.3 \%$ of fibers. Sterculia rhinopetala had the lowest percentage of fibers with $43 \%$. In vessel proportion, Blighia sapida had the proportion of $11.5 \%$ and a vessel density of $12 \mathrm{vessel} / \mathrm{mm}^{2}$, followed by Sterculia rhinopetala with $7.3 \%$ and vessel density of 7 vessels $/ \mathrm{mm}^{2}$ and Albizia ferruginea with lowest proportion of vessels at $5.8 \%$ and vessel density of 6 vessels $/ \mathrm{mm}^{2}$. Of the three species, Albizia ferruginea had an average vessel lumen diameter of $215 \mu \mathrm{m}$ (maximum $310 \mu \mathrm{m}$, minimum $121 \mu \mathrm{m}$ ). Blighia sapida had an average vessel lumen diameter of $178 \mu \mathrm{m}$ (maximum $281 \mu \mathrm{m}$, minimum $91 \mu \mathrm{m}$ ) whilst Sterculia rhinopetala had an average vessel lumen diameter of 164 $\mu \mathrm{m}$ (maximum $257 \mu \mathrm{m}$, minimum $85 \mu \mathrm{m}$ ). Sterculia rhinopetala had the highest proportion of axial parenchyma of 34.3\% followed by $23 \%$ of axial parenchyma in Albizia ferruginea. Axial parenchyma was however not distinct in Blighia sapida. Proportion of rays was in the order of $24.3 \%, 15.5 \%$, and $8 \%$ for Blighia sapida, Sterculia rhinopetala and Albizia ferruginea respectively. Sterculia rhinopetala had twice as thick walled fibers as Blighia sapida, with average double fiber wall thickness of $806 \mu \mathrm{m}$ and $432 \mu \mathrm{m}$ respectively. Albizia ferruginea had an avearge double fiber wall thickness of $374 \mu \mathrm{m}$. With a mean fiber length of between $1474-1899 \mu \mathrm{m}$ (Table 2), Sterculia rhinopetala had the longest fibers of the three selected species but the mean vessel lumen diameter was the smallest of the three species with a value of $164 \mu \mathrm{m}$. Albizia ferruginea had mean vessel lumen diameter value of $215 \mu \mathrm{m}$ which was the largest of the three species while having relatively short fibers which ranged from 1196 - $1274 \mu \mathrm{m}$. Blighia sapida had a mean vessel lumen diameter of $178 \mu \mathrm{m}$ and a mean fiber length of between 1127 - $1303 \mu \mathrm{m}$. This brings to the fore the fact that Sterculia rhinopetala has thick long fibers 


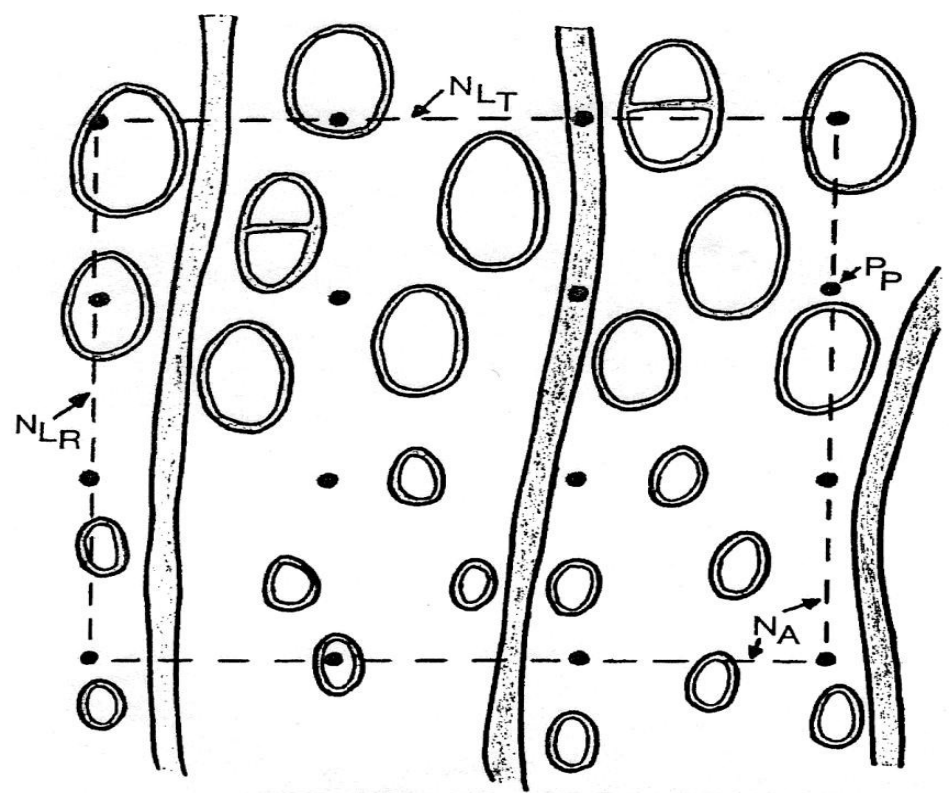

Figure 2. Counting grid used for stereological counts taken from Beery et al. 1982. $\mathrm{P}_{\mathrm{p}}$ isarea fractions of anatomical elements; $\mathrm{NL}_{\mathrm{R}}$ and $\mathrm{NL}_{\mathrm{T}}$ are the number of elements per unit length of the test line in the radial and tangential directions and $\mathrm{N}_{\mathrm{A}}$ is the number of elements per unit area.

Table 1. Proportion of tissues (and standard deviation) in the three species.

\begin{tabular}{|c|c|c|c|c|c|c|}
\hline Species & Fibers (\%) & Vessel (\%) \& vessel density & Axial parenchyma (\%) & Rays (\%) & DFWT $(\mu \mathrm{m})$ & Density $\left(\mathrm{g} / \mathrm{cm}^{3}\right)$ \\
\hline \multirow[t]{2}{*}{ Albizia ferruginea } & $63.3(2.7)$ & $5.8(1.5)$ & $23(1.9)$ & $8(0.7)$ & $374(0.7)$ & 0.603 \\
\hline & & 6 vessels $/ \mathrm{mm}^{2}$ & & & & \\
\hline \multirow[t]{2}{*}{ Blighia sapida } & $64.3(4.3)$ & $11.5(4.5)$ & - & $24.3(3.6)$ & $432(0.9)$ & 0.892 \\
\hline & & 12 vessels $/ \mathrm{mm}^{2}$ & & & & \\
\hline \multirow[t]{2}{*}{ Sterculia rhinopetala } & $43(2.6)$ & $7.3(1.1)$ & $34.3(1.3)$ & $15.5(2.3)$ & $806(1.3)$ & 0.945 \\
\hline & & 7 vessels $/ \mathrm{mm}^{2}$ & & & & \\
\hline
\end{tabular}

Legend: DFWT—Double fiber wall thickness.

Table 2. Range of mean values for fiber length and vessel lumen diameter of the three selected wood species (with the maximum and minimum values in parenthesis).

\begin{tabular}{ccc}
\hline Species & Fiber length $(\mu \mathrm{m})$ & Vessel lumen diameter $(\mu \mathrm{m})$ \\
\hline Albizia ferruginea & $1196-1274$ & $215(121-310)$ \\
Blighia sapida & $1127-1303$ & $178(91-281)$ \\
Sterculia rhinopetala & $1479-1899$ & $164(85-257)$ \\
\hline
\end{tabular}

with small vessel lumen diameter whilst Albizia ferruginea had relatively short fibers with wide vessel lumens.

Qualitative analyses of the anatomical investigations are shown in micrographs in Figures 3(a)-(k). Figure 3(a) shows the transverse section of Albizia ferruginea showing solitary vessels with radial multiples of 2 - 4 vessels. Some of the vessels were occluded with tyloses. The axial parenchymas were arranged paratracheal, vasicentric, aliform and confluent. In the tangential section, Figure 3(b), the rays were storied and filled with inclusions.

The photomicrographs (Figures 4(a)-(e)) explain further observations made with the light microscope. Figure 3(a) Showed Albizia ferruginea with tyloses in vessel and Figure 4(a) enhances this feature; the tyloses. In 


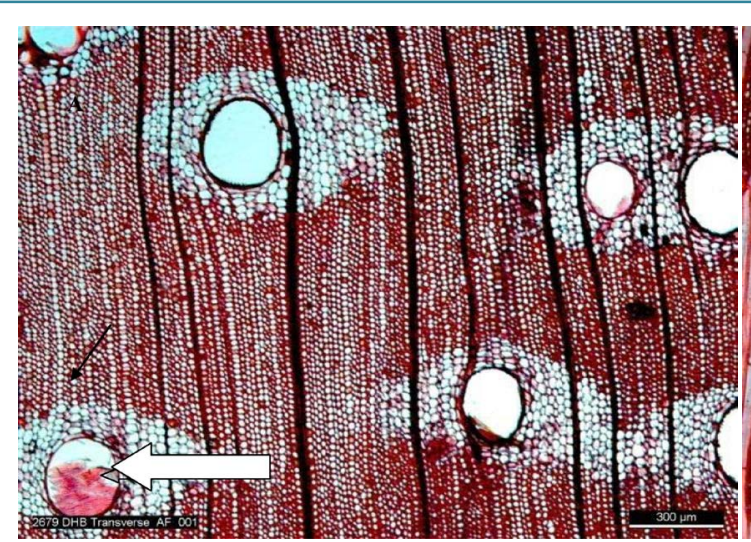

(a)

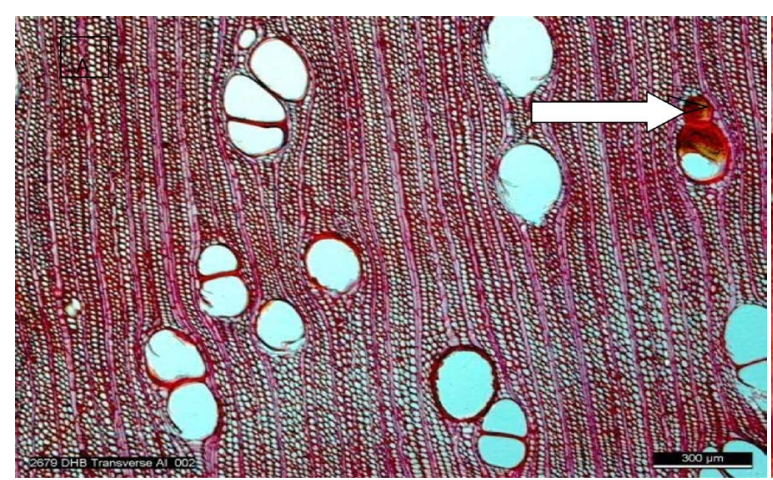

(c)

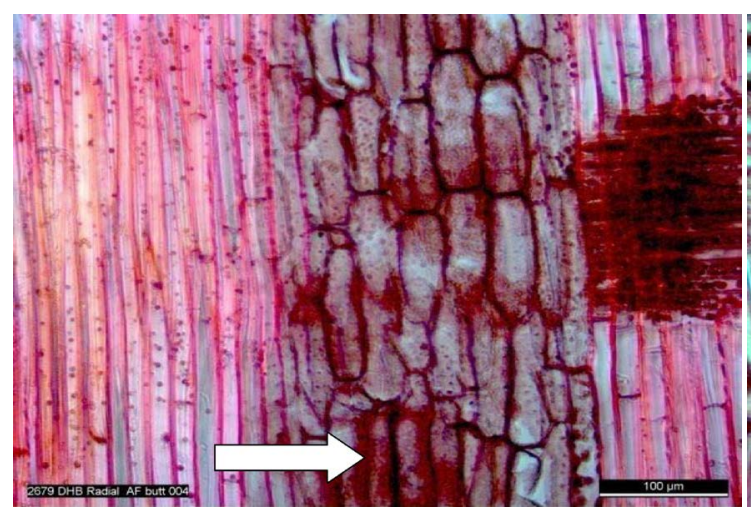

(e)

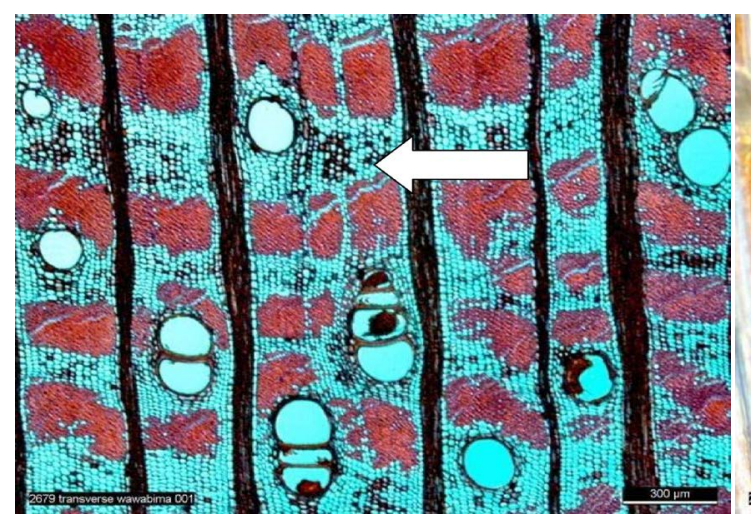

(g)

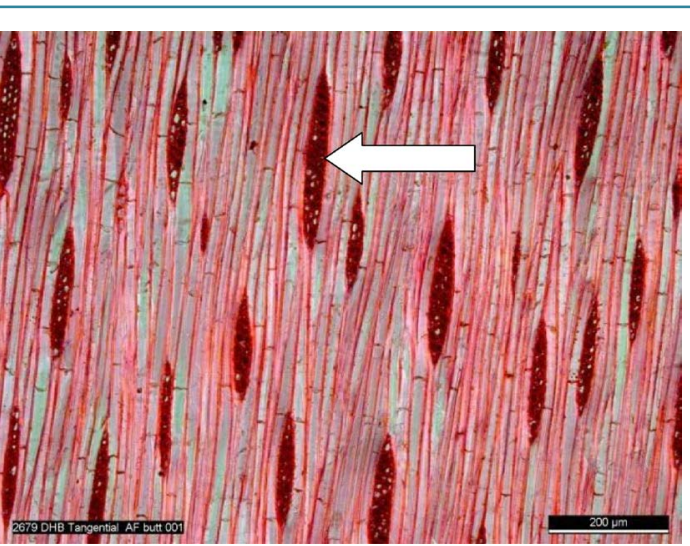

(b)

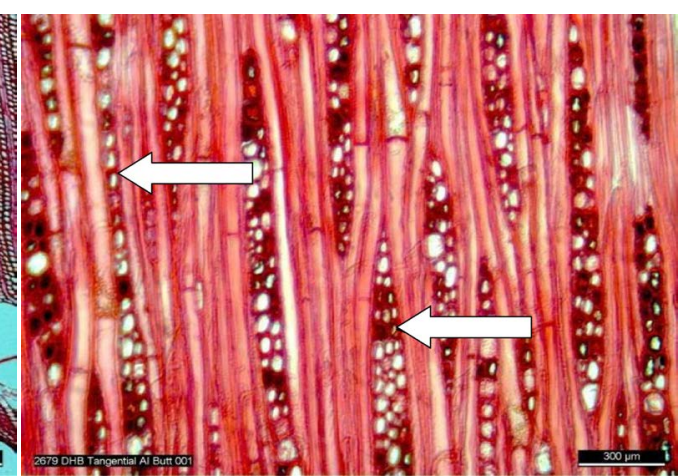

(d)

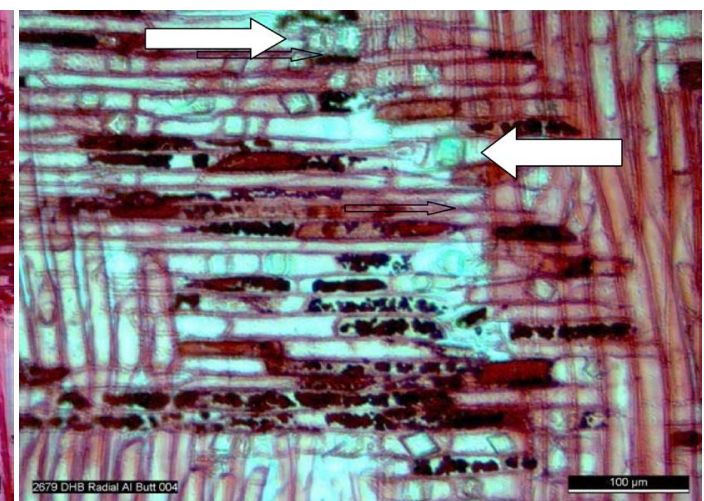

(f)

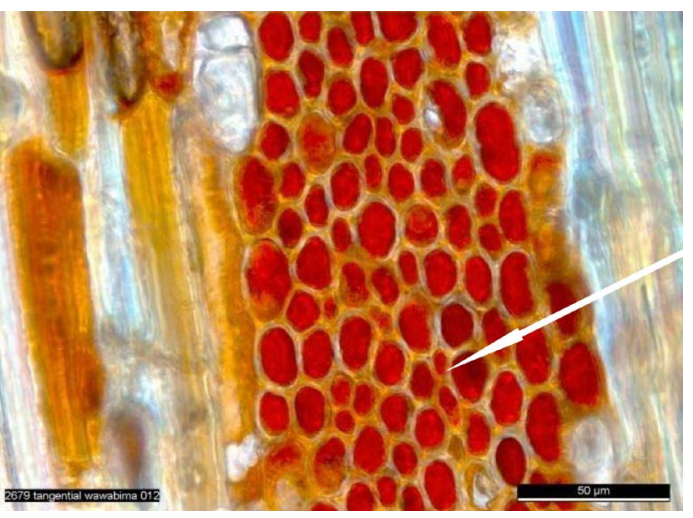

(h) 


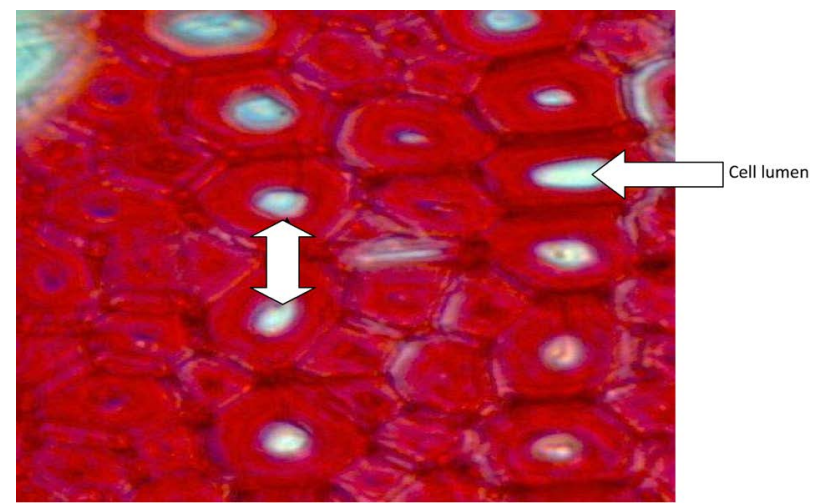

(i)

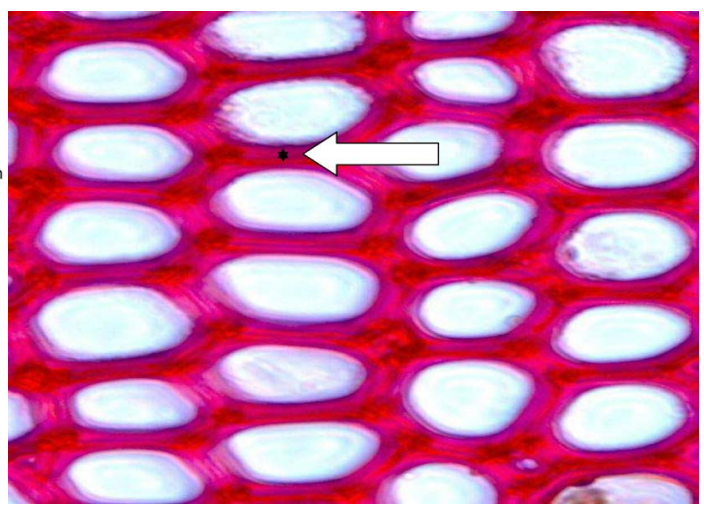

(j)

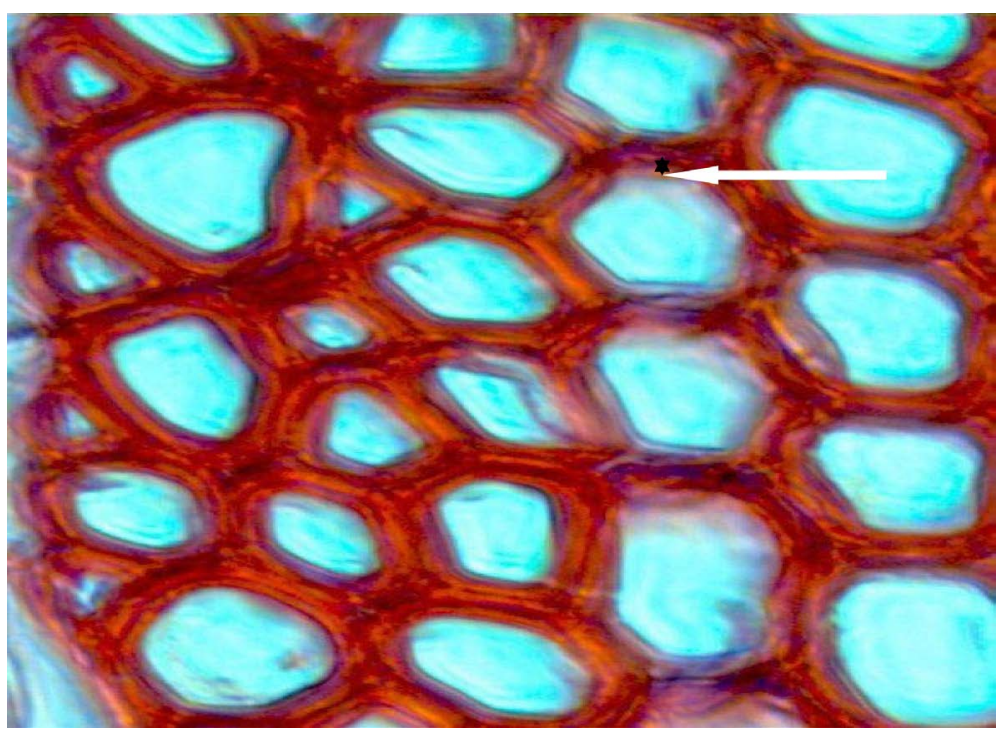

(k)

Figure 3. (a) Transverse section of Albizia ferruginea showing a vessel with tylosis (arrowed) and axial parenchyma aliform and confluent paratracheal. Scale bar $=300 \mu \mathrm{m}$. (b) Tangential section of Albizia ferruginea showing storied rays filled with inclusions (arrowed). Scale bar $=200 \mu \mathrm{m}$. (c) Transverse section of Blighia sapida showing solitary vessels in radial multiples of $2-4$. Scale bar $=300 \mu \mathrm{m}$ Tylosis occluded some of the vessels (arrowed). Axial parenchyma was not distinct. (d) Tangential section of Blighia sapida showing multiseriate (arrowed) and uniseriate (also arrowed) heterocellular rays with inclusions. Scale bar $=300 \mu \mathrm{m}$. (e) Radial section of Albizia ferruginea showing mutiseriate rays with inclusions. Scale bar $=100 \mu \mathrm{m}$. (f) Radial section of Blighia sapida with ray cells containing some prismatic crystals (arrowed). Scale bar $=100 \mu \mathrm{m}$. (g) Transverse section of Sterculia rhinopetalawith storied and straight to wavy broad-banded axial parenchyma with inclusions. Vessels are solitary and in radial multiples with tyloses and inclusions. Fibers are also banded. Ray parenchyma was variable, wide and narrow. Scale bar $=300 \mu \mathrm{m}$. (h) Unstained Tangential section of Sterculia rhinopetalawith rays (arrowed) filled with inclusions. Scale bar $=50 \mu \mathrm{m}$. (i) Transverse sections of Sterculia rhinopetaladepicting the presence of thick-walled fibers (arrowed). (j) Transverse sections of Albizia ferruginea showing thin walled fibers. (k) Blighia sapida medium walled fibers (arrowed).

the same way, Figure 3(g). depicted rays in Sterculia rhinopetala filled with inclusions. Figure 4(b) threw more light on this feature. The sculptured wall of vessels and occluded pits in Blighia depicted in Figure 3(c) and Figure 3(d) was also better understood and seen properly in Figures 4(c)-(e) enhances the crystals in the rays seen in Figure 3(f).

The anatomical features identified macroscopically by Oteng-Amoako et al. [16] for Albizia ferruginea are that the vessels were medium and solitary with inclusions present this has been made clearer by the microscopic study as seen in Figure 3(a). More so, the macroscopic identification indicated that the axial parenchyma was as seen in Figure 3(a). The axial parenchyma is present and appears as aliform and confluent paratracheal and in the tangential section the rays are storied and also filled with inclusions (Figure 3(b)) whilst the macroscopic 


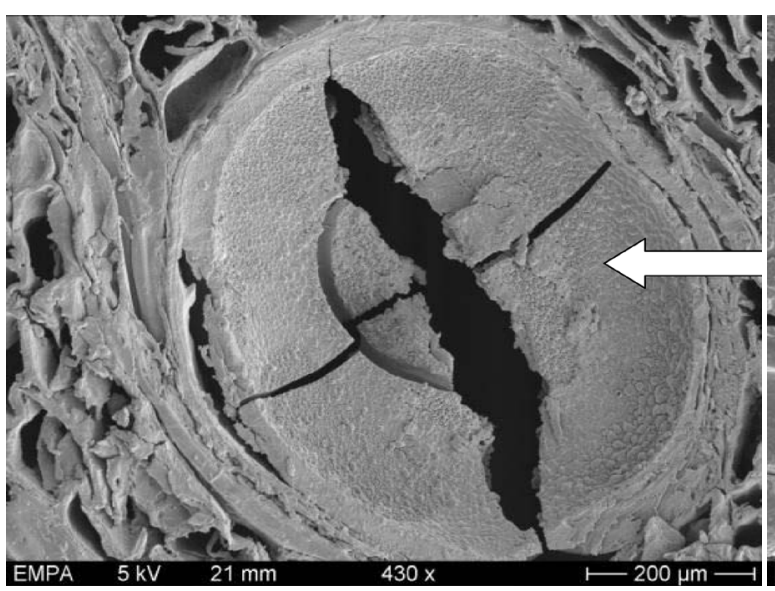

(a)

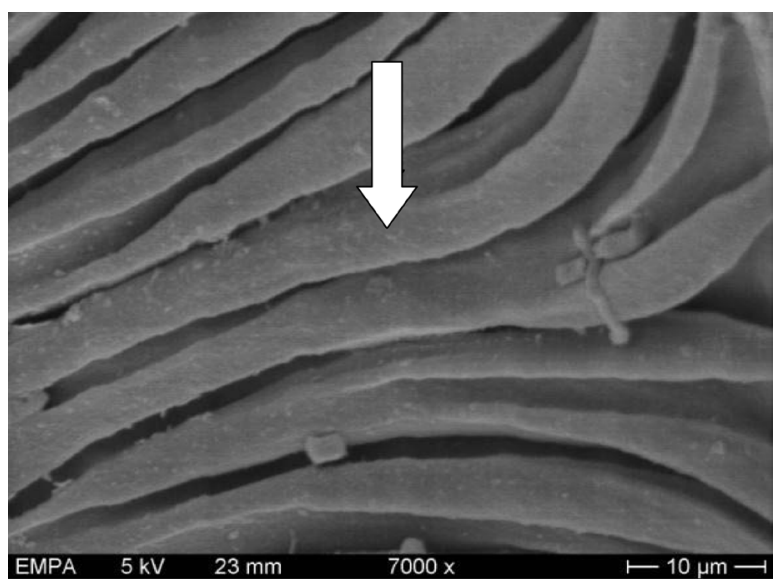

(c)

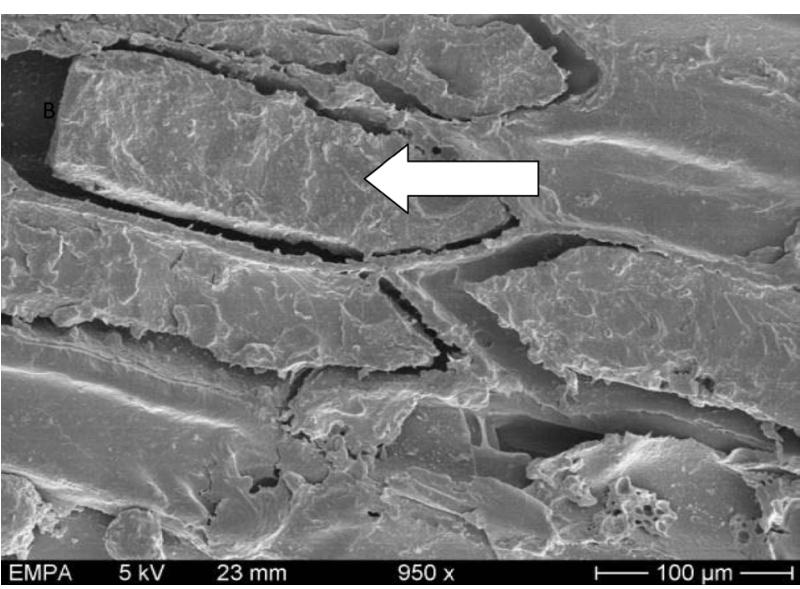

(b)

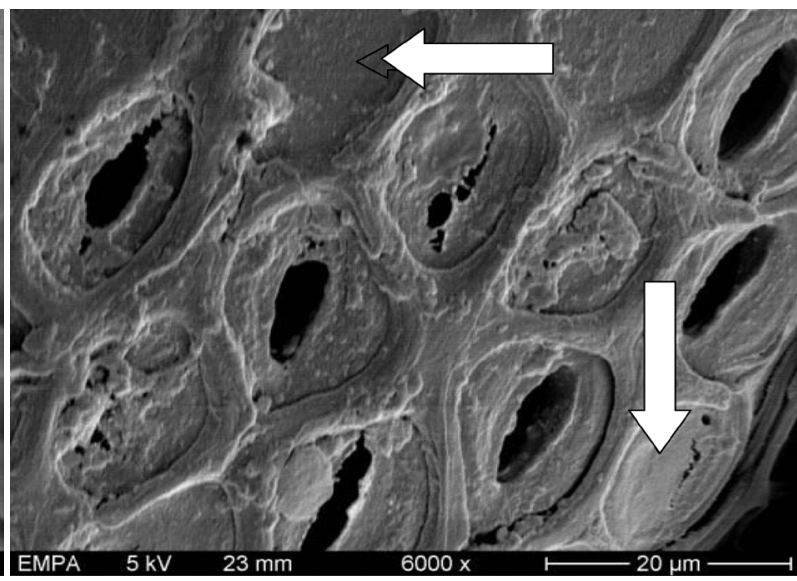

(d)

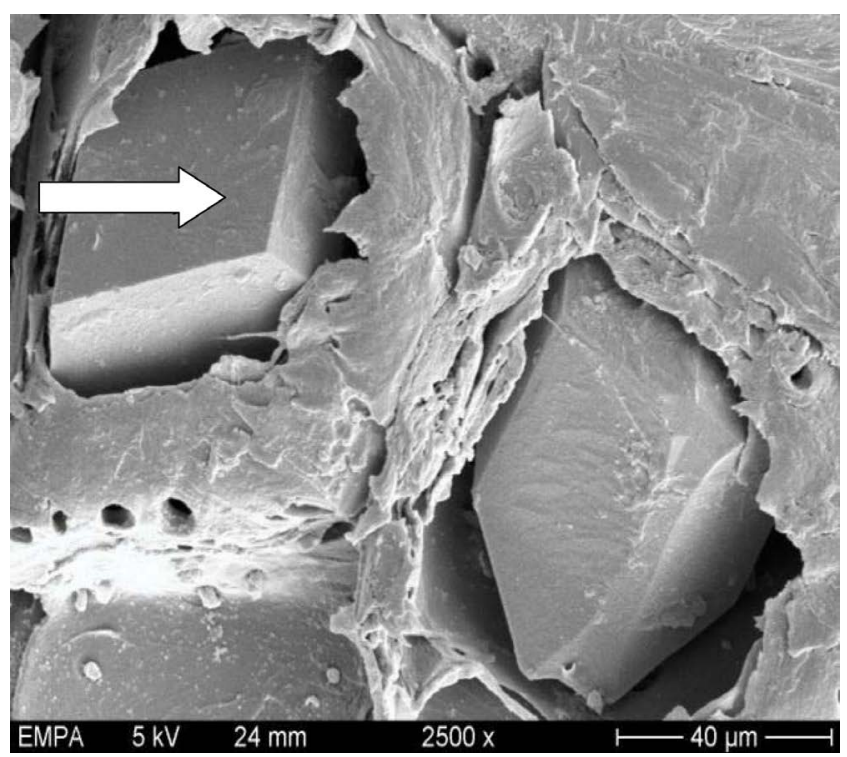

(e)

Figure 4. (a) A vessel of Albizia ferruginea occluded with tylosis (arrowed). Scale bar $=200 \mu$ m. (b) Parenchyma of Sterculia rhinopetala filled with substances (arrowed). Scale bar $=100 \mu \mathrm{m}$. (c) Sculptured vessel wall (arrowed) of Blighia sapida. $10 \mu \mathrm{m}$. (d) Some occluded pits (arrowed) of Blighia sapida. Scale bar $=20 \mu \mathrm{m}$. (e) Some crystals embedded in the rays of Blighia sapida. Scale bar $=40 \mu \mathrm{m}$. 
identification did not indicate the inclusions in the rays for the same species. According to an author, vessel diameter and vessel distribution have effect on water conduction efficiency [17]. Therefore with vessel distribution of 6 vessels $/ \mathrm{mm}^{2}$, and a maximum vessel lumen diameter of $310 \mu \mathrm{m}$ it could be expected of Albizia ferruginea to have high water uptake. Formation of tyloses in this species may be another reason for its high durability, since tyloses apparently assist in restricting pathogen movement [18]. He indicated that, in elm trees, tyloses formation was correlated with increased resistance to Dutch elm disease.

For Blighia sapida, features identified macroscopically which was also confirmed microscopically were vessels distribution with inclusions, axial parenchyma not distinct and ray parenchyma not distinct however the microscopic tangential section gives a very distinct heterocellular ray parenchyma which are multiseriate and uniseriate (Figure 3(d)). Furthermore, the SEM micrographs Figure 4(c)-(e) throws more light on how sculptured the vessels are, that there are not just inclusions in the vessels but some of the vessels are occluded as well as have prismatic substances in some of the vessel lumens (Figures 3(f) and Figure 4(e)) which will help to better understand the wood when in use. Vessel wall sculpturing as seen in Figure 4(c) agreed with the findings [19]. Prismatic crystals occurring in the ray cells as depicted in Figure 3(f) and highlighted by SEM micrographs in Figure 4(c) was also confirmed [19]. The presence of these substances could blunt tools when this species is being sawed and also occupy sites where water could have occupied thereby contributing to lower water/moisture uptake.

Sterculia rhinopetala had fewer fibers than the other two species. Most of its fibers had thicker walls and that could account for its high bending strength and density. Since according to the authors, fiber wall thickness is closely linked with density, i.e. the thicker the wall, the higher the density [20]. From Figure 4(b), it was seen that Sterculia rhinopetala had almost all its axial parenchyma occluded with substance which probably maybe the polyphenols and this could be responsible for its durability. The actual composition of the substances was yet to be identified. These substances could also act as bulking agents preventing moisture intake and for that matter water. The low water uptake of Sterculia rhinopetala can be explained by the fact that thick-walled fibers go hand in hand with thick-walled vessels and therefore low water uptake.

Another advantage of having thick-walled vessels was narrow vessel lumens which leads to resistance to embolism; that is the situation where gases fill the conduit and leads to cavitation. This was because it has been stated that the spread of embolisms within a conducting element, and from vessel element to element through the perforation plates, causes the entire vessel to become dysfunctional [18]. Ewers [21] prepared a diagram of a trade-off triangle of wood functions and associated anatomical features, the points of the triangle being 1) resistance to embolism (narrow vessels), 2) conductive efficiency (wide vessels), and 3) mechanical strength (thick-walled fibers). It was proposed that there is a negative relationship between mechanical strength and conductive efficiency and a positive relationship between mechanical strength and safety. Wheeler et al. [22] in discussing the variation in global dicotyledon wood anatomy, asserts that woods with thick-walled fibers have thick-wall vessels which result in low conductive efficiency. Therefore it is understandable that Sterculia rhinopetala with thick-walled fibers has low water uptake due to narrow vessel lumen. In the same way, another author stated that the characteristics of these fibrous cells and their arrangement affect strength properties, appearance, and resistance to penetration by water and chemical solutions, resistance to decay and many other properties [23].

\section{Conclusions}

We studied Albizia ferruginea, Blighia sapida, and Sterculia rhinopetala all belonging to the lesser utilised wood species. We found out that Albizia ferruginea had on the average two out of six of its vessels occluded with tyloses. These tyloses and inclusions occluded some of the vessels of this species thereby lowering the uptake of substances such as water and also prevent pathogen movement. These inclusions which are organic may be hydrophilic, accounting for the high water uptake even though it is highly durable. Such observation has also been found as reported and cited in International Agency for Research on Cancer (IARC) [24] monograph, indicating that some extractives such as tannins are polar and are generally able to dissolve in water making them hydrophilic [25].

We also identify cell wall sculpturing and the presence of prismatic substances in the cell lumen of Blighia sapida which may affect transfer of substance between cells. The crystals may also affect machining of the wood by blunting the tools. The occluded pits of Blighia sapida could also hinder transportation of water and minerals between the cells. 
Lastly but not the least, we noticed that narrow vessel lumens in Sterculia rhinopetala also affected water uptake and therefore made the wood species less permeable and the thick cell walls also made this wood very strong and stiff.

Anatomical features and structures studied helped explain the results of the properties of the wood species. It was possible to make certain predictions about wood properties from careful anatomical examinations. Accordingly woods with many thick-walled cells would be stronger, heavier and stiffer than wood with thin-walled elements. Some anatomical features like fibre wall thickness have an effect on the bending strength of the species. Some inclusions which may include extractives found in Albizia ferruginea and Sterculia rhinopetala could be responsible for their natural durability. The use of scanning electron microscopy (SEM) to examine the anatomical and ultrastructural aspects of wood has been found to be a useful approach to a clearer understanding of the features and structures found in wood.

It has enabled us to identify some of the features that are not visible macroscopically, for example, the presence of crystals in Blighia sapida and the thick-walled fibers of Sterculia rhinopetala and the absence of axial parenchyma in Blighia sapida.

\section{Acknowledgements}

I am grateful to Professor Maurice Brunner, Prof. Dr Ernst Zurcher and Dr. Thomas Volkmer all of the University of Applied Science, Biel in Switzerland for their guidance and support during my stay with them. I also want to thank the Swiss National Science Foundation and Get Fund for financial support. Final thanks goes to my supervisor, Prof. Frimpong Mensah of Kwame Nkrumah University of Science and technology.

\section{References}

[1] Wagenführ, R. (2000) Holzatlas Fachbuchverlag, Leipzig, München.

[2] Cobbinah, J.R. (1998) Welcome Address. International Conference on Value-Added Processing and Utilisation of Lesser-Used Timber Species. Forestry Research Institute of Ghana. International Timber Trade Organization and Timber Export Development Board, Proceedings, 1.

[3] Kuffour, B. (1998) Increased Utilization of Lesser-Used Species-Social and Economic Impact. Technical Session 111. Processing and Product Development International Conference on Value-Added Processing and Utilisation of LesserUsed Timber Species. Forestry Research Institute of Ghana (FORIG), International Timber Trade Organisation (ITTO) and Timber Export Development Board, Proceedings, 1.

[4] Timber Industry Development Division (2004) Report on Export of Wood Products. May 2004.

[5] Timber Industry Development Division (2007) Report on Export of Wood Products, May 2007, 49.

[6] Jayanetti, D.L. (1998) Lesser-Used Timber Species in Construction. Technical Session V. Timber Engineering and ReConstituted Wood. International Conference on Value-Added Processing and Utilisation of Lesser-Used Timber Species. Forestry Research Institute of Ghana (FORIG), International Timber Trade Organisation (ITTO) and Timber Export Development Bureau (TEDB) Proceedings, 145-156.

[7] Zziwa, A., Bukenya, M. Sseremba, O.E. and Kyeyune, R.K. (2006) Non-Tradition a Tree Species Used in the Furniture Industry in Masaka District, Central Uganda. Uganda Journal of Agricultural Sciences, 12, 57-66.

[8] Towler, R.W. (1975) The Possibilities of Increased Consumption of the Lesser-Known Tropical Hardwood Species. The Commonwealth Forestry Review, 54, 243-249.

[9] Anon (1994) The Tropical Timbers of Ghana. Timber Export Development Board. Tarkoradi, Ghana.

[10] Okai, R. (1998) Recent Advances in Machining of Lesser-Used Species. International Conference on Value-Added processing and Utilisation of Lesser-Used Timber Species. Forest Research Institute of Ghana (FORIG), International Timber Trade Organisation (ITTO) and Timber Export Development Bureau (TEDB) Proceedings, 95-104.

[11] Wayne, R.O., Whaley, W.G. and Cocking, E.C. (2014) Plant Cell. Access Science from McGraw-Hill Education.

[12] Taneda, K., Kawakami, H., Ishida, S. and Ohtani, J. (1979) Observation of the Polymer in Wood-Polymer Composite. I. Dissolution of Wood Substance in WPC and Shape of the Polymer Cast. Mokuzai Gakkaishi, 25, 209-215.

[13] Smulski, S. and Cote, W.A. (1984) Penetration of Wood by Water-Borne Alkyd Resin. Wood Science and Technology, 18, 59-75. http://dx.doi.org/10.1007/BF00632131

[14] Ifju, G. (1983) Quantitative Wood Anatomy-Certain Geometrical-Statistical Relationships. Wood and Fiber Science, 15, 326-337.

[15] Steele, J.H., Ifju, G. and Johnson, J.A. (1976) Quantitative Characterisation of Wood Microstructure. Journal of Mi- 
croscopy, 107, 297-311. http://dx.doi.org/10.1111/j.1365-2818.1976.tb02450.x

[16] Oteng-Amoako, A.A., Zurcher, E., Agyakumhene, I., Ebanyenle, E. and Rogenmoser, C. (2006) 100 Tropical African Timber Trees from Ghana. Tree Description and Wood Identification with Notes on Distribution, Ecology, Silviculture, Ethnobotany and Wood Uses. Graphic Publications Inc., Millersburg, 304 p.

[17] Zimmermann, M.H. (1982) Functional Xylem Anatomy of Angiosperm Trees. In: Baas, P., Ed., New Perspectives in Wood Anatomy, Martinus Nijhoff, The Hague, 59-70. http://dx.doi.org/10.1007/978-94-017-2418-0_3

[18] Dickson, W.C. (2000) Integrative Plant Anatomy. Academic Press, San Diego, 533 p.

[19] Klaassen, R. (1999) Wood Anatomy of the Sapindaceae. International Association of Wood Anatomists Journal, 20, 75-76.

[20] Herenden, P.S. and Miller, R.B. (2000) Utility of Wood Anatomical Characters in Cladistic Analysis. International Association of Wood Anatomists Journal, 21, 247-276.

[21] Baas, P., Ewers, F.W., Davies, S.D. and Wheeler, E.A. (2004) The Evolution of Xylem Physiology. In: Hemsley, A.R. and Poole, I., Eds., The Evolution of Plant Physiology. From Whole Plants to Ecosystems, Linnaean Society Symposium Series No. 21, Academic Press, Waltham, 273-296. http://dx.doi.org/10.1016/b978-012339552-8/50016-0

[22] Wheeler, E.A., Baas, P. and Rodgers, S. (2007) Variations in Dicot Wood Anatomy: A Global Analysis Based on the Insidewood Database. International Association of Wood Anatomists Journal, 28, 229-258.

[23] Miller, R.B. (2014) Wood Anatomy. Access Science from McGraw-Hill Education. Timber Export Development Bureau (TEDB) Proceedings, 74-76.

[24] International Agency for Research on Cancer (1995) Monographs on the Evaluation of the Carcinogenic Risk of Chemicals to Humans. Wood Dust and Formaldehyde, 62, A-1-A-6.

[25] Fengel, D. and Wegener, G. (1989) Wood—Chemistry, Ultrastructure, Reactions. 2nd Edition, Walter de Gruyter, Berlin. 